\title{
グリオーマの標準治療と試験治療としての免疫療法
}

橋本 直哉

京都府立医科大学大学院医学研究科脳神経機能再生外科学 (脳神経外科学)

\section{A Review of Standard Therapeutic Approaches and Clinical Trials for treating Gliomas with an Eye towards the Immunotherapy Future}

\author{
Naoya Hashimoto, M.D. \\ Department of Neurosurgery, Kyoto Prefectural University Graduate School of Medicine
}

The standard treatment for glioma is surgery, followed by extended local irradiation and chemotherapy. In patients with newly diagnosed glioblastoma (GBM), however, combined radiotherapy (RT) and temozolomide (TMZ) treatment followed by adjuvant TMZ for at least 6 months offers a modest benefit, with a median survival of 14.6 months. Currently, therapeutic options with evidence confirming their efficacy in glioma patients are limited, although some new approaches, such as carmustine wafers and bevacizumab, are available for clinical use in many countries. Thus, surgical maximal resection followed by combined RT and TMZ is still recognized as the standard therapy for newly diagnosed GBM. In this review, focusing on surgery with photodynamic diagnosis with 5 -aminolevulinic acid, carmustine wafers, bevacizumab and talaporfin sodium, the world and domestic standard approaches against gliomas were extensively reviewed with an implication for the new WHO classification emerging in this year. In addition, cancer immunotherapy against gliomas, which is expected as the next generation of standard care, is introduced and thoroughly reviewed.

(Received August 8, 2016; accepted September 9, 2016)

Key words : glioma, standard treatment, immunotherapy, glioblastoma, oligodendroglial tumor Jpn J Neurosurg（Tokyo） $25: 922-927,2016$

\section{はじめに}

グリオーマには多くのがんと同様に，手術摘出，放射 線療法, 化学療法を柱とした集学的治療が行われる。し かしながらその治療成績は悲観的で, 最も悪性度の高い 膠芽腫の 2 年生存率は $20 \%$ 以下とされる ${ }^{29)}$. 2006 年に なって日本でも認可された化学療法剤, テモゾロミド (temozolomide) が標準的治療の一部として普及している が, 放射線治療単独群に比してテモゾロミド併用群では
2.5 力月程度の生存期間の延長をみるのみである ${ }^{25)}$ 。こ のことは，膠芽腫をはじめとするグリオーマの治療には 標準治療とされている手術による最大摘出・放射線・化 学療法に加え得る何らかの治療法が必要であることを示 している.

表題に「グリオーマの標準治療」としたが，がん情報 サイト（http://cancerinfo.tri-kobe.org）によれば，標準 治療とは「科学的根拠に基づいた観点で, 現在利用でき る最良の治療であることが示され，ある状態の一般的な

連絡先：橋本直哉, $\bar{\top} 602-8566$ 京都市上京区河原町通り広小路上る梶井町 465 京都府立医科大学大学院医学研究科脳神経機能 再生外科学

Address reprint requests to: Naoya Hashimoto, M.D., Department of Neurosurgery, Kyoto Prefectural University Graduate School of Medicine, 465 Kajii-cho, Kawaramachi-dori Hirokoji-agaru, Kamigyo-ku, Kyoto-shi, Kyoto 602-8566, Japan 
Surgical resection

with PDD (5-ALA)

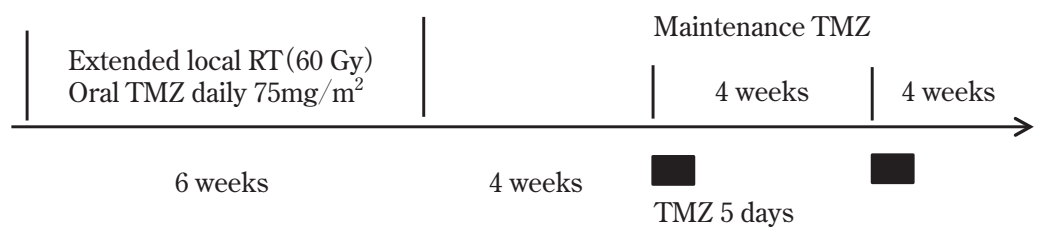

Fig. 1 A community (domestic) standard treatment of newly diagnosed glioblastoma in early 2016

Surgical maximal resection with PDD (photodynamic diagnosis) using 5ALA (5-aminolevulinic acid) and combined radiation/temozolomide (TMZ) therapy, followed by maintenance TMZ of 24-36 cycles.

患者さんに行われることが推奨される治療」である。こ の「科学的根拠」を randomized controlled trial (RCT) と すれば，グリオーマの種類の中で標準治療とみなされ得 るものが存在するのは, わずかに膠芽腫 (WHO gradeIV) と退形成性乏突起膠腫系腫瘍（grade III）のみである.

日本では WHO 分類に基づいて脳腫瘍の診療が行われ ているが，2007 年に改定された第 4 版 ${ }^{13)}$ から 9 年を経 て，本年には新たな版（第 5 版）が公刊された ${ }^{14)}$ 。その 改訂の大きな特色は，分子遺伝学的分類を診断名に取り 入れたということにある。たとえば，改訂された新WHO 分類では，従来の乏突起膠腫は，「之突起膠腫，1p/19q 欠失あり」,「乏突起膠腫， $1 \mathrm{p} / 19 \mathrm{q}$ 欠失なし」などと診断 名が分かれる、本総説では新分類も念頭に置きながら, しかし多くのエビデンスは旧 WHO 分類に基づいて行わ れた RCT の結果によるものであり，基本的には「旧分類 によるグリオーマ」の標準治療について述べる.

さらに本総説では, 複数のがん腫ですでに標準治療と なっており, 現在も治験を含む臨床試験が精力的に行わ れている免疫療法について, 試験治療の代表としてその 概要を述べる.

\section{グリオーマの標準治療}

\section{1 膠芽腫}

国内では少なくとも 2013 年に複数の薬剤がグリオー マに対しての保険適応を取得するまでは, 2005 年に発表 されたいわゆるStupp regimen ${ }^{26)}$ が膠芽腫に対する標準 治療と考えられていた。 2013 年, 国内では術中光線力学 的 (蛍光) 診断薬である 5-aminolevurinic acid (5-ALA), アルキル化剤の脳内留置剤である carmustine（BCNU） wafer, 抗 VEGF-R (vascular endothelial growth factor receptor）抗体である bevacizumab, 術中光線力学的治療 薬としての talaporfin sodium が薬事承認され, 保険適応
を取得した。このうち 5-ALAについては国内の多数の医 療機関にて, 2004 年頃から臨床研究として導入されてい た。また 2008 年にはドイツから RCT の結果が報告され ており ${ }^{25)}$ ，現時点では「5-ALAによる最大摘出に続くテ モゾロミド同調放射線療法と維持テモゾロミド」が，国 内における膠芽腫の標準治療であると考元られる（Fig. 1)。ここで留意すべきは，Stupp らの原著によれば，維 持テモゾロミドは最大 6 クールであるが，日本では最大 24〜36クールを行うことが許容されていることである. テモゾロミドには用量依存性に 2 次発がんの危険性があ ることが指摘されており ${ }^{15)}$, 筆者らは, まずは 24 クール まで維持しその後は症例に応じて対応している. 分子生 物学的には, IDH mutation 予後良好因子とされており, MGMT (O6-methylguanine DNA methyltransferase) のメ チル化については，当初テモゾロミドに対する治療反応 性の予測因子とされたが ${ }^{10)}$, 現在では放射線単独治療群 でもメチル化群で予後良好であることが示され，これも 予後良好因子ともされている.

ここでは，新たに認可された $4 つ の$ 新規薬剤について の基本的事項を解説しておく.

\section{5-ALA による最大摘出}

5-ALA は薬剤として投与されると腫瘍細胞に選択的 に取り込まれ，細胞内でへムの合成経路に入り，プロト ポルフィリンIXが生成される。特定波長（405 nm）の励 起光を照射すると赤色蛍光を発し，蛍光誘導下に摘出す ると, 摘出率と無増悪生存期間が改善することが示され $た^{25)}$. 本薬剤は，光過敏症以外の患者で，その安全性が 確立している。「本薬剤 (5-ALA) による最大摘出に続く テモゾロミド同調放射線療法」が，国内における膠芽腫 の標準治療と考元られる。

\section{Carmustine (BCNU) wafer}

アルキル化剤である carmustine（BCNU）を合成ポリ マーの基剤に溶け込ませた留置型の抗がん剂で, 2003 年 
に臨床第III相の RCT 結果が発表されたが31), その報告に よれば grade III とIVを含んだ悪性グリオーマにおいて, 本剂留置群とプラセボ留置群では，全生存期間に統計的 有意差が認められた。しかし, 膠芽腫（grade IV）のみ を抽出しサブ解析を行うと有意差が認められず，世界的 にもこれを膠芽腫の標準治療とするかについては賛否両 論がある.

\section{Bevacizumab}

再発膠芽腫に対する臨床試験 $(B E L O B \text { 試験 })^{5)}$ でその 有効性が認められたものの, 2013 年に発表された初発膠 芽腫に対する 2 つ国際 RCT では1 ${ }^{29}$, 全生存期間(OS) では統計学的有意差を検証できず, 議論の対象になって いる. 本薬剤の特徴として MRI 上, pseudo-response (偽 性反応) を示し, 脳浮腫を軽減, performance status（PS） を改善することが挙げられる。日本は本薬剤を初発の膠 芽腫に対して承認した唯一の国であり, 初発膠芽腫に対 する使用頻度は低くない. 初発膠芽腫の 30〜 40\%におい てPSが悪く，そのステロイド様効果を期待する臨床家 が少なくないものと考えられる。

\section{Talaporfin sodium}

1.における光線力学的（蛍光）診断が photodynamic diagnosis（PDD）と呼ばれるのに対し, 本剤を代表とす る光感受性物質を腫瘍細胞に取り込ませて高エネルギー の励起光を照射し, 生じる活性酸素により細胞死を誘発 する治療は photodynamic therapy（PDT）と称される。 本剂は日本で開発されて, 肺癌の一部などで保険承認と なったあと, グリオーマにも保険適応が認められた。大 規模な RCTの結果はなく, 今後の研究成果を待たなけれ ばならない17)。

\section{2 退形成性乏突起膠腫}

乏突起膠細胞系腫瘍のうち, 旧 WHO 分類 (2007) に おける grade III, すなわち退形成性乏突起膠腫と退形成 性乏突起星細胞腫（混合性腫瘍）については, RCT とそ の長期成績から標準治療が確立していると考えられる. 乏突起膠細胞系の腫瘍群は, これまでの分子細胞遺伝学 的研究から, 正常細胞ないしは腫瘍前駆細胞に $I D H$ mutation をきたし, さらに 1p/19q codeletion が加わって 発生すると考えられている2

1p/19q codeletion については, 1990 年代半ばから退形 成性乏突起膠腫と退形成性乏突起星細胞腫 (混合性腫瘍) に特異的にみられることがわかっていた ${ }^{8)}$. 最近の RCT により本異常を有する群 $(1 \mathrm{p} / 19 \mathrm{q}$ codeletion) と有さな い群（1p/19q non-codeletion）では予後に有意の差があ り, 本異常はバイオマーカーであることが明らかになっ

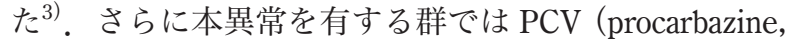
CCNU, vincristine) 療法が放射線単独治療群に比して有 意な生存期間をもたらすことが判明し, 乏突起膠系腫 瘍, 1p/19q codeletion 群の標準治療と考元れている.

\section{グリオーマに対する試験治療 一免疫療法を中心に一}

国内はもとより世界では多数の試験治療, すなわち臨 床試験が行われている。代表的には中性子捕捉療法 （BNCT）や陽子線治療といった放射線治療, 数々の分子 標的薬や抗体薬物複合体を含む薬物療法が挙げられる. 中には, 電場治療（tumor treating field：TTF）のように 欧米の臨床試験でその効果が証明されながらも27), 日本 では保険適応のない特殊な状況の治療もある。ここで は, 将来的に有望視されつつある試験治療として, 免疫 療法についてその概略に触れる。

近年では細胞障害性 (キラー) T 細胞 (cytotoxic T cell： CTL）が抗腫瘍効果を示すことが明らかになり ${ }^{18)}, \mathrm{CTL}$ に認識されるがん関連抗原が多数同定されたことなどか $ら^{6)}$, グリオーマに対する免疫療法は再度, その有効性 と副作用の少ない点から標準的治療に組み込み得るもの として期待されている (Fig. 2). CTLの標的となるがん 関連抗原のうち, グリオーマに発現が認められるものが 多数明らかになった. NCI (National Cancer Institute) が 75 種類のがん関連抗原について, その有用性のランキン グを行い, WT1 と EGFRvIIIが上位に位置づけられた4). また, 免疫担当細胞とがん細胞の間で直接的に免疫を抑 制する機構が解明され，免疫チェックポイントとよばれ る ${ }^{23)}$ 。これを阻害するチェックポイント阻害剤は有意に がんに対する免疫を増強することが明らかとなり，ほか のがん腫では標準治療になっているものもある ${ }^{21)}$.

\section{1. がん関連抗原を用いた免疫療法（腫瘍ワクチン療} 法)

がん関連抗原を標的とした免疫療法には，樹状細胞を 用いた免疫療法, 自家腫瘍ワクチン, ペプチドワクチン 療法に大別される。樹状細胞（dendritic cell：DC）を用 いた免疫療法では，グリオーマでの DC ワクチンの臨床 第 I / II 相試験で, その安全性のみが確認された ${ }^{24) 32)}$. 自 家腫瘍ワクチンでは, 組織標本から抽出した腫瘍とア ジュバントを投与する自家腫瘍ワクチン療法が開発さ れ, 膠芽腫 12 例を対象とした研究では, 有効例は CR (complete response) 1例, PR (partial response) 1例で あった ${ }^{11)}$.

ペプチドワクチン療法では, 変異型 EGFRvIII産物を 


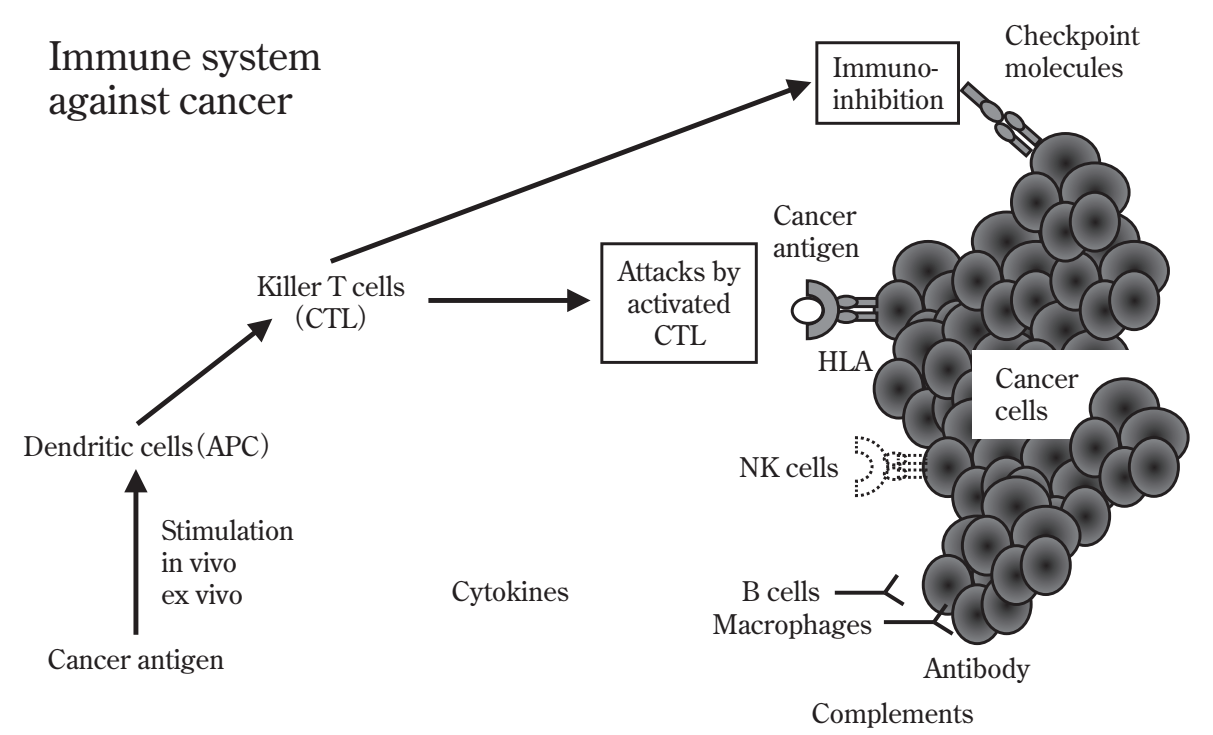

Fig. 2 Cancer immunotherapy utilizes various immune-cells and humoral factors

The main effector is cytotoxic T cells (CTL, killer T cells), which attack cancer cells by targeting cancer antigens expressed on HLA (human leukocyte antigen) molecules. Dendritic cell or peptide based antigens is administered to activate the CTL in modern cancer immunotherapies.

NK : natural killer

標的とした EGFRvIII ペプチドワクチン療法の多施設第 II 相試験において，初発膠芽腫 21 例に対し標準治療で ある放射線/テモゾロミド療法後に EGFRvIII と KLH (keyhole limpet hemocyanin) アジュバントが投与され, 有効性が認められた ${ }^{22)}$ 。筆者らはWT1 遺伝子産物を標 的とした WT1 ペプチドワクチン療法を開発し，再発膠 芽腫 21 例に単独で投与する第 II 相試験を行い，再発か らの無増悪生存期間の中央值は 5 力月で，臨床的有効性 が示された ${ }^{12)}$ ．テモゾロミド標準治療と複合した第 $\mathrm{I}$ 相 試験では，その安全性と免疫学的応答が確認された ${ }^{9)}$. その他，複数の抗原を標的にしたペプチドを，カクテル 化して投与する試みが行われている。再発悪性グリオー マ 12 例に対して，14 種類のペプチドから患者ごとに選 択されたカクテルワクチンの第 I 相試験が行われ，PR 2 例，生存期間中央值は 10.6 力月で, 臨床的有効性が示さ れた ${ }^{28)}$.

\section{2. エフェクター細胞療法と免疫抑制阻害療法}

エフェクター細胞療法として, T 細胞輸注療法 ${ }^{7}$, $\mathrm{T}$ 細 胞受容体 (TCR) 遺伝子導入 $\mathrm{T}$ 細胞療法 ${ }^{16)}{ }^{20}$ ) が考案され ている。また，免疫の抑制機構を阻害する免疫チェック ポイント阻害療法では, CTLA-4 や PD-1/PD-L1 に対す る抗体がすでに薬剤として開発されている。本治療は免 疫療法としては有害事象が多く, 中には重篤例も報告さ れているため，その点ではほかの免疫療法に劣るが，グ
リオーマにおいても治験が進行中である。

\section{3. 免疫療法における臨床的課題}

免疫療法の効果判定は, 放射線/化学療法とは異なり, 即効性に乏しいため，新たな判定基準が提案，模索され ている ${ }^{19)}$ ．臨床試験の生物統計解析や試験デザインその ものも免疫療法に特化する必要があり, 免疫学的モニ夕 リングの確立，バイオマーカーの検索や強力なアジュバ ントの開発など，免疫学的に残された課題も多い.

\section{おわりに}

本総説では，2016 年初頭の時点で，グリオーマに対す る標準治療と考えられている治療法について述べそその 実際と問題点につき詳述した。また，近い将来に科学的 に有効性が認められる可能性が高い免疫療法についても 原理および問題点などを総論的に述べた。

$\mathrm{COI}$

筆者である橋本直哉は開示すべき潜在的利益相反状態はあ りません。

\section{文 献}

1) Addeo R, Perri F, Parlato C, Della Vittoria G : ASCO 2013 : bevacizumab and glioblastoma - a marriage dissolution? 
Curr Med Res Opin $\quad 30:$ 1871-1873, 2014.

2) Arita H, Narita Y, Fukushima S, Tateishi K, Matsushita Y, Yoshida A, Miyakita Y, Ohno M, Collins VP, Kawahara N, Shibui S, Ichimura K : Upregulating mutations in the TERT promoter commonly occur in adult malignant gliomas and are strongly associated with total $1 \mathrm{p} 19 \mathrm{q}$ loss. Acta Neuropathol 126: 267-276, 2013.

3) Cairncross G, Wang M, Shaw E, Jenkins R, Brachman D, Buckner J, Fink K, Souhami L, Laperriere N, Curran W, Mehta M : Phase III trial of chemoradiotherapy for anaplastic oligodendroglioma : long-term results of RTOG 9402. J Clin Oncol 31:337-343, 2013.

4) Cheever MA, Allison JP, Ferris AS, Finn OJ, Hastings BM, Hecht TT, Mellman I, Prindiville SA, Viner JL, Weiner LM, Matrisian LM : The prioritization of cancer antigens : a national cancer institute pilot project for the acceleration of translational research. Clin Cancer Res 15:5323-5337, 2009.

5) Friedman HS, Prados MD, Wen PY, Mikkelsen T, Schiff D, Abrey LE, Yung WK, Paleologos N, Nicholas MK, Jensen R, Vredenburgh J, Huang J, Zheng M, Cloughesy T : Bevacizumab alone and in combination with irinotecan in recurrent glioblastoma. J Clin Oncol 27 : 4733-4740, 2009.

6) Galon J, Costes A, Sanchez-Cabo F, Kirilovsky A, Mlecnik B, Lagorce-Pagès C, Tosolini M, Camus M, Berger A, Wind P, Zinzindohoué F, Bruneval P, Cugnenc PH, Trajanoski Z, Fridman WH, Pagès F : Type, density, and location of immune cells within human colorectal tumors predict clinical outcome. Science $313:$ 1960-1964, 2006.

7) Gattinoni L, Powell DJ Jr, Rosenberg SA, Restifo NP : Adoptive immunotherapy for cancer: building on success. Nat Rev Immunol $\quad 6: 383-393,2006$.

8) Hashimoto N, Ichikawa D, Arakawa Y, Date K, Ueda S, Nakagawa Y, Horii A, Nakamura Y, Abe T, Inazawa J : Frequent deletions of material from chromosome arm 1p in oligodendroglial tumors revealed by double-target fluorescence in situ hybridization and microsatellite analysis. Genes Chromosomes Cancer 14:295-300, 1995.

9) Hashimoto N, Tsuboi A, Kagawa N, Chiba Y, Izumoto S, Kinoshita M, Kijima N, Oka Y, Morimoto S, Nakajima H, Morita S, Sakamoto J, Nishida S, Hosen N, Oji Y, Arita N, Yoshimine T, Sugiyama H: Wilms tumor 1 peptide vaccination combined with temozolomide against newly diagnosed glioblastoma : safety and impact on immunological response. Cancer Immunol Immunother $\quad$ 64: 707-716, 2015.

10) Hegi ME, Diserens AC, Gorlia T, Hamou MF, de Tribolet N, Weller M, Kros JM, Hainfellner JA, Mason W, Mariani L, Bromberg JE, Hau P, Mirimanoff RO, Cairncross JG, Janzer RC, Stupp R : MGMT gene silencing and benefit from temozolomide in glioblastoma. N Engl J Med 352: 997-1003, 2005.

11) Ishikawa E, Tsuboi K, Yamamoto T, Muroi A, Takano S, Enomoto T, Matsumura A, Ohno T : Clinical trial of autologous formalin-fixed tumor vaccine for glioblastoma multiforme patients. Cancer Sci 98: 1226-1233, 2007.

12) Izumoto S, Tsuboi A, Oka Y, Suzuki T, Hashiba T, Kagawa N, Hashimoto N, Maruno M, Elisseeva OA, Shirakata T, Kawakami M, Oji Y, Nishida S, Ohno S, Kawase I, Hatazawa J, Nakatsuka S, Aozasa K, Morita S, Sakamoto J, Sugiyama $\mathrm{H}$, Yoshimine $\mathrm{T}$ : Phase II clinical trial of Wilms tumor 1 peptide vaccination for patients with recurrent glioblastoma multiforme. J Neurosurg 108: 963-971, 2008.
13) Louis DN, Ohgaki H, Wiestler OD, Cavenee WK, Burger PC Jouvet A, Scheithauser BW, Kleihues P: The 2007 WHO classification of tumours of the central nervous system. Acta Neuropathol 114: 97-109, 2007.

14) Louis DN, Perry A, Reifenberger G, von Deimling A, Figarella-Branger D, Cavenee WK, Ohgaki H, Wiestler OD, Kleihues P, Ellison DW : The 2016 World Health Organization Classification of Tumors of the Central Nervous System : a summary. Acta Neuropathol 131: 803-820, 2016.

15) Momota S, Narita Y, Miyakita Y, Shibui S : Secondary hematological malignancies associated with temozolomide in patients with glioma. Neuro Oncol $15:$ 1445-1450, 2013.

16) Morgan RA, Dudley ME, Wunderlich JR, Hughes MS, Yang JC, Sherry RM, Royal RE, Topalian SL, Kammula US, Restifo NP, Zheng Z, Nahvi A, de Vries CR, Rogers-Freezer LJ, Mavroukakis SA, Rosenberg SA : Cancer regression in patients after transfer of genetically engineered lymphocytes. Science 314:126-129, 2006.

17) Muragaki Y, Akimoto J, Maruyama T, Iseki H, Ikuta S, Nitta M, Maebayashi K, Saito T, Okada Y, Kaneko S, Matsumura A, Kuroiwa T, Karasawa K, Nakazato Y, Kayama T : Phase II clinical study on intraoperative photodynamic therapy with talaporfin sodium and semiconductor laser in patients with malignant brain tumors. J Neurosurg 119: 845-852, 2013.

18) Oka Y, Tsuboi A, Taguchi T, Osaki T, Kyo T, Nakajima H, Elisseeva OA, Oji Y, Kawakami M, Ikegame K, Hosen N, Yoshihara S, Wu F, Fujiki F, Murakami M, Masuda T, Nishida S, Shirakata T, Nakatsuka S, Sasaki A, Udaka K, Dohy H, Aozasa K, Noguchi S, Kawase I, Sugiyama H : Induction of WT1 (Wilms' tumor gene) - specific cytotoxic T lymphocytes by WT1 peptide vaccine and the resultant cancer regression. Proc Natl Acad Sci U S A 101: 13885-13890, 2004.

19) Okada H, Weller M, Huang R, Finocchiaro G, Gilbert MR, Wick W, Ellingson BM, Hashimoto N, Pollack IF, Brandes AA, Franceschi E, Herold-Mende C, Nayak L, Panigrahy A, Pope WB, Prins R, Sampson JH, Wen PY, Reardon DA : Immunotherapy response assessment in neuro-oncology : a report of the RANO working group. Lancet Oncol 16 : e534-542, 2015.

20) Restifo NP, Dudley ME, Rosenberg SA : Adoptive immunotherapy for cancer : harnessing the T cell response. Nat Rev Immunol 12:269-281, 2012.

21) Robert C, Long GV, Brady B, Dutriaux C, Maio M, Mortier L, Hassel JC, Rutkowski P, McNeil C, Kalinka-Warzocha E, Savage KJ, Hernberg MM, Lebbé C, Charles J, Mihalcioiu C, Chiarion-Sileni V, Mauch C, Cognetti F, Arance A, Schmidt H, Schadendorf D, Gogas H, Lundgren-Eriksson L, Horak C, Sharkey B, Waxman IM, Atkinson V, Ascierto PA: Nivolumab in previously untreated melanoma without BRAF mutation. N Engl J Med 372: 320-330, 2015.

22) Sampson JH, Heimberger AB, Archer GE, Aldape KD, Friedman AH, Friedman HS, Gilbert MR, Herndon JE 2nd, McLendon RE, Mitchell DA, Reardon DA, Sawaya R, Schmittling RJ, Shi W, Vredenburgh JJ, Bigner DD : Immunologic escape after prolonged progression-free survival with epidermal growth factor receptor variantIII peptide vaccination in patients with newly diagnosed glioblastoma. $J$ Clin Oncol 28: 4722-4729, 2010.

23) Schreiber RD, Old LJ, Smyth MJ : Cancer immunoediting : integrating immunity's roles in cancer suppression and promotion. Science 331: 1565-1570, 2011. 
24) Steinman RM, Banchereau J : Taking dendritic cells into medicine. Nature 449:419-426, 2007.

25) Stummer W, Reulen HJ, Meinel T, Pichlmeier U, Schumacher W, Tonn JC, Rohde V, Oppel F, Turowski B, Woiciechowsky C, Franz K, Pietsch T ; ALA-Glioma Study Group : Extent of resection and survival in glioblastoma multiforme : identification of and adjustment for bias. Neurosurgery 62:564-576, 2008.

26) Stupp R, Mason WP, van den Bent MJ, Weller M, Fisher B, Taphoorn MJ, Belanger K, Brandes AA, Marosi C, Bogdahn U, Curschmann J, Janzer RC, Ludwin SK, Gorlia T, Allgeier A, Lacombe D, Cairncross JG, Eisenhauer E, Mirimanoff RO ; European Organisation for Research and Treatment of Cancer Brain Tumor and Radiotherapy Groups ; National Cancer Institute of Canada Clinical Trial Groups: Radiotherapy plus concomitant and adjuvant temozolomide for glioblastoma. N Engl J Med 352: 987-996, 2005.

27) Stupp R, Wong ET, Kanner AA, Steinberg D, Engelhard H, Heidecke V, Kirson ED, Taillibert S, Liebermann F, Dbalý V, Ram Z, Villano JL, Rainov N, Weinberg U, Schiff D, Kunschner L, Raizer J, Honnorat J, Sloan A, Malkin M, Landolfi JC, Payer F, Mehdorn M, Weil RJ, Pannullo SC, Westphal M, Smrcka M, Chin L, Kostron H, Hofer S, Bruce J, Cosgrove R, Paleologous N, Palti Y, Gutin PH : NovoTTF-100 A ver- sus physician's choice chemotherapy in recurrent glioblastoma : a randomized phaseIII trial of a novel treatment modality. Eur J Cancer 48:2192-2202, 2012.

28) Terasaki M, Shibui S, Narita Y, Fujimaki T, Aoki T, Kajiwara K, Sawamura Y, Kurisu K, Mineta T, Yamada A, Itoh K : Phase I trial of a personalized peptide vaccine for patients positive for human leukocyte antigen -A24 with recurrent or progressive glioblastoma multiforme.J Clin Oncol 29 : 337-344, 2011.

29) The Committee of Brain Tumor Registry of Japan : Report of Brain Tumor Registry of Japan (1969-1996). Neurol Med Chir (Tokyo) 43 Suppl: i-vii, 2003.

30) Weller M, Yung WK : Angiogenesis inhibition for glioblastoma at the edge : beyond AVAGlio and RTOG 0825. Neuro Oncol 15:971, 2013.

31) Westphal M, Hilt DC, Bortey E, Delavault P, Olivares R, Warnke PC, Whittle IR, Jääskeläinen J, Ram Z: A phase 3 trial of local chemotherapy with biodegradable carmustine (BCNU) wafers (Gliadel wafers) in patients with primary malignant glioma. Neuro Oncol 5: 79-88, 2003.

32) Yu JS, Liu G, Ying H, Yong WH, Black KL, Wheeler CJ : Vaccination with tumor lysate-pulsed dendritic cells elicits antigen-specific, cytotoxic T-cells in patients with malignant glioma. Cancer Res 64: 4973-4979, 2004.

グリオーマの標潐治療と試験治療としての免疫療法

橋本 直哉

グリオーマの治療成績は悲観的で, 代表的なグリオーマである膠芽腫の全生存期間は 14.6 力月とさ れる. このことは標準治療とされている手術・放射線・化学療法に加え得る何らかの治療法が必要で あることを示している. 本総説では, まず「標準治療とは何か」について考え, WHO 新分類の意義 と実際を念頭に置きながら, 2016 年初頭におけるグリオーマの世界標準および国内標準の治療につ いて述べた. 特に光線力学的診断を駆使した蛍光誘導手術とその成績, テモゾロミド以外に国内で使 用できる薬物や治療について, その適応と問題点を明らかにした. また, 試験治療の例として次世代 の標準治療として期待される免疫療法についても概説した. 